\title{
NEWS OVERLOAD IN SPAIN: THE ROLE OF DEMOGRAPHIC CHARACTERISTICS, NEWS INTEREST, AND CONSUMER PAYING BEHAVIOR
}

\section{Manuel Goyanes}

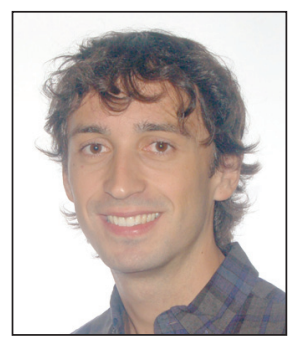

Manuel Goyanes has a PhD in communication science from the University of Santiago de Compostela and master's degree in statistics (Universidad Politécnica de Madrid). Currently, he is a post-doc in media management at Carlos III University of Madrid. He has presented at several international congresses and published in international journals such as Journalism practice, International journal on media management, and First Monday. His research interests include information overload, consumer culture, and entrepreneurial intention.

http://orcid.org/0000-0001-8329-0610

Carlos III University of Madrid Madrid, 133. 28903 Getafe (Madrid), Spain manuel.goyanes@uc3m.es

\begin{abstract}
This article explores factors that correlate with the perception of news overload and the extent to which Spaniards feel overloaded, or not, with the amount of news available. Specifically, this study explores the following factors: demographics (age, gender, and income), news interest, and consumer paying behavior for online news. The research method employs a quantitative, explorative approach with data collected from an online survey of 1,439 Spanish adults, 18 years and older, in January 2013. Finally, managerial and theoretical implications are discussed.
\end{abstract}

\section{Keywords}

News overload, news interest, consumer paying behavior, online newspapers, online news.

Título: Sobrecarga informativa en España: el rol de variables demográficas, el interés en las noticias y el comportamiento de pago del consumidor

\section{Resumen}

La presente investigación explora factores noveles que presumiblemente afectan a la percepción de sobrecarga informativa, así como analiza su nivel de expansión en España. Particularmente, el estudio analiza el rol de diferentes variables demográficas (sexo, edad e ingresos), el interés por las noticias y el comportamiento de pago del consumidor por su periódico digital favorito. Para ello la investigación aplica una aproximación cuantitativa y exploratoria a través de una encuesta a 1.439 adultos españoles realizada en enero de 2013. Por último, se discuten las implicaciones teóricas y gerenciales.

\section{Palabras clave}

Sobrecarga informativa, Interés por las noticias, Comportamiento de pago, Diarios digitales, Noticias online.

Goyanes, Manuel (2014). "News overload in Spain: the role of demographic characteristics, news interest, and consumer paying behavior". El profesional de la información, v. 23, n. 6, November-December, pp. 618-624.

http://dx.doi.org/10.3145/epi.2014.nov.09

\section{Introduction}

Over the last two decades the amount of information available has dramatically increased (Serra, 2004). This trend has been exacerbated by the rise of the Internet; more specifically by the World Wide Web in the 1990s and later by the advent of social networking tools (Bawden; Robinson, 2009). The large increase of available information is exemplified with a few statistics: everyday more than 3,000 books are published worldwide; the number of documents on the Internet doubled from 400 million to 800 million from 1998 to 2000; more information has been created in the past 30 years than in the previous 5,000 years; and the weekly edition of the New York Times contains more information than an average person was likely to come across in his lifetime during the seventeenth-century in England (Bawden, 2001). This vast oversupply of information is increasingly causing psychological and physiological problems, ranging from 
increased levels of stress when working through email inboxes to anxiety about keeping up with multiple social networking sites such as Facebook and Twitter (Swartz, 2011; Bregman, 2012).

The problems associated with information overload have been addressed in several disciplines including consumer behavior, information science, management information systems, marketing, and organizational communication. Communication scholars are now interested in information overload; specifically how news consumption behavior might trigger or complement problems associated with information overload. Nordenson (2008) points out that some newspapers' readers are suffering increased levels of news fatigue. A clear example of this trend is the US pattern of news consumption: despite the fact that the majority of the American adults get news content from multiple news outlets, an important segment of consumers report problems associated with an incapacity to process information and, even more surprisingly, with discerning between important and useless information. As a result, some scholars (Hermida, 2010) have theorized that news consumption behavior could be described as "ambient news," suggesting that news content is ubiquitous and omnipresent.

The problems associated with information overload have been addressed in several disciplines

News consumption of traditional media is on the decline while its digital counterpart is on the rise. Therefore, media managers are focusing their efforts on maintaining and increasing audiences while also monetizing the digital product. Since the profitability and relevance of news organizations are being threatened by new - and practically freecontent, studying how to reduce or decrease the actual or perceived level of news overload for online newspaper consumers deserves an empirical examination. Previous empirical research in this area has focused only on the analysis of information overload by consumers in the US. Therefore, we can only speculate about how the findings can be generalized to other populations such as those in European countries where the attitudes and news consumption patterns are different. Thus, the main objective of the present research is to analyze news content as a form of information overload, examining the extent to which Spaniards feel overloaded with the amount of available news. Also, this study explores factors that correlate with the perception of news overload and the extent to which Spaniards feel overloaded, or not, with the amount of news available. Specifically, this study explores the following factors: demographics (age, gender, and income), news interest, and consumer paying behavior for online news. Theoretical and managerial implications are discussed.

\section{Theoretical framework}

News consumption and delivery has dramatically changed since the arrival of the Internet. Now, more than ever, tra- ditional media have been challenged by new digital media, from both inside and outside the journalism profession, as the main and central providers of information and entertainment (Picard, 2003). This competition has created a saturation of news content and platforms (Holton; Chyi, 2012) and can contribute to the psychological feeling of information overload. Despite the fact that there is no single generally accepted definition of information overload, the term usuaIly represents a state of affairs where an individual's efficiency in using information is hampered by the large amount of relevant, and potentially useful, information available to them (Bawden; Robinson, 2009). According to Bawden, Hotman, and Courtney (1999), information overload occurs when the amount of available content becomes difficult to process, often causing negative feelings for the end user. In addition, some other psychological conditions have been associated with information overload, such as continuous partial attention (Stone, 2008), attention deficit (Hallowell, 2005), cognitive overload (Kirsh, 2000), and technostress (Thornton, 2007).

The omnipresent nature of information in the current digital panorama is intensified by the popularity of different digital devices (tablets, smartphones, e-readers, etc.) that enable the user to continuously consume updated information. Some segments of the US population rely on multiple news media sources (Diddi; LaRose, 2006, Pew Research, 2010), and according to Pew Research (2014), 92 percent of American adults get news content from multiple platforms on a typical day-half of those using four to six platforms daily ${ }^{1}$. While news viewership and readership in traditional media are declining, when online and mobile consumption are included, consumers actually spend more time with news products (Pew Research Center, 2010). Consumers may prefer to read the news online, but they continue to read the news (Chyi; Chadha, 2011). In this context, where the digital content is omnipresent and its access is at hand to any user by a simple click at anytime, the number of cases of people that suffer news overload is increasing.

The main objective of the present research is to analyze news content as a form of information overload

Previous research studies have analyzed the impact of different news delivery platforms on news overload. For example, Holton and Chyi (2012) found news access through platforms and outlets such as computers, e-readers, and Facebook had a positive association with overload, whereas other platforms such as television and the iPhone were negatively associated with overload. On the other hand, one demographic factor, gender (being female), was positively related to news overload whereas two other demographic factors, age and income, were negatively associated with news overload (Ji, Ha; Sypher, 2014). Personal preference, such as news interest, was a significant and negative predictor (Holton; Chyi, 2012), that is, people who enjoy keeping up with news are less likely to suffer news overload. 
In regards to perceived news overload, 141 (24.5 percent) of respondents in one study said they had never experienced information overload; while 434 (75.5 percent) replied they had experienced some level of news overload (Ji, Ha; Sypher, 2014).

In spite of the theoretical and empirical contributions of these previous studies, there is a surprising lack of research focused on non-US samples. Therefore, we can only speculate about how the findings can be generalized to other populations such as those in European countries where the attitudes and news consumption patterns are different. For example, in Spain various online media outlets are used for news consumption but are not as widespread as in the US (Reuters, 2013). Furthermore, tablet penetration in Spain is not as high as in the US, despite the fact that smartphone use for information consumption in Spain is one of the highest in the world. In this context, with the aim of measuring how Spaniards feel with the amount of news content now available and how demographic variables and news interest influence the perception of news overload, this study asked the following research questions:

RQ1: To what extent do Spaniards feel overloaded with the amount of news available?

RQ2: How does news interest influence the perceived degree of news overload?

In addition, this study aims to determine if there is a relationship between consumers' paying behavior and news overload. This relationship has not been studied previously; however, the recent increase of digital paywalls in various news organizations allows us to empirically test whether there are significant differences between paid and non-paid readers with respect to the level of news overload. According to the Pew Research Center (2014), digital pay plans are being adopted at 450 US news outlets including major news organizations (such as The New York Times and Wall Street Journal) and also small and mid-sized papers (Mitchell, 2013). With regard to Spain, digital pay plans are exponentially increasing, although notable is the complete absence of the freemium and metered model (Goyanes; Dürremberg, 2014).

The exploratory analysis of this relationship is important for several reasons. First, because it will compare consumer behavior patterns between free vs. paid news consumption with respect to news overload. Second, because the analysis may provide managerial insights that help reduce news overload among Spanish news consumers. Finally, the results may help managers choose appropriate business models and design effective revenue-generation methods. Therefore, this study includes a third research question:

RQ3: Are Spanish consumers who are paying for their favorite online newspaper more or less likely to suffer news overload when compared to those who consume free news?

\section{Method}

A randomly selected sample of 1,439 Spanish adults (18 years and older) were administered an online survey between January 14 and $17,2013^{2}$ to examine the perception of news overload in Spanish Internet users. The participants were recruited by snowball sampling (Atkinson; Flint, 2001). Snowball sampling may simply be defined as a technique for finding research subjects. One subject gives the researcher the name of another subject, who in turn provides the name of a third, and so on (Vogt; Johnson, 2001). This technique is a widely used method, especially for research with an exploratory nature in which the descending methodologies (such as household surveys) can suffer a lack of responses from particular groups-usually young people and unemployed males (Atkinson; Flint, 2001). Ascending methodologies, such as the use of snowball techniques, can be used to work upwards and locate those on the ground who are needed to fill in the gaps in our knowledge on a variety of social contexts. In this sense, snowball sampling can be considered as an alternative or as a complementary strategy for attaining more comprehensive data on a particular research question (Atkinson; Flint, 2001).

In spite of the theoretical and empirical contributions of previous studies, there is a surprising lack of research focused on non-US samples

The survey was distributed via web communities and social networking sites such as Twitter and Facebook. Personal networks of the researchers were employed and also the accounts and pages of Spanish newspapers. The sample size of 1,439 yielded a standard sampling error of \pm 3.1 percentage points at the 95 percent confidence level. The sample included slightly more women (57.1 percent, $N=822$ ) than men (42.9 percent, $N=617$ ) with an age range between 18 and 85 . The survey took an average of five minutes to complete. Each participant was asked to enter his or her account number and password before participating in the survey to ensure the sample included no duplications. The participation $^{3}$ (or completion rate) was 70.45 percent. In this study, in terms of statistical power, the overall sample size $(1,439$ respondents) contributes to the stability of statistical analysis since larger sample sizes tend to produce more reliable sample estimates. The survey sample of 1,439 was compared with the Internet population of Spain for control variables (i.e. age, gender, and income) to ensure representation. In this case, the survey sample overrepresented females and people with lower income. The survey sample was weighted to these two particular variables. The final weighted sample size was 1,445 . In general, the weighted sample is comparable to the population in terms of gender, age, and income but underrepresented those with an age between 24 and 44 years old.

The survey focused on the factors that trigger the perception of news overload. A questionnaire was created by three university academics and then pilot-tested on four graduate students and on six academics (one post-doctoral fellow, two assistant professors, one associate professor, and two full professors). Their comments on the content of the survey instrument, item wording, terminology, and clarity were 
incorporated into a revised instrument. Next, the refined instrument was piloted again on a larger sample of 50 university students (which are not part of the sample), and final revisions were made.

The measurement of news overload was operationalized asking respondents the level of agreement with the following statement "I often feel overload with the amount of news available these days" on a four-point Likert scale with anchors ranging from 1 = Completely disagree; 4 = Completely agree. Despite being a construct measured by a single item, previous empirical research has employed the same operationalization (Chyi; Chadha, 2012; Ji, Ha; Sypher, 2013). News interest was measured by asking respondents: "In general, how much do you enjoy keeping up with the news?" on a four-point Likert scale with anchors ranging from $1=$ Not at all and $4=A$ lot. This measurement was adopted from Pew Research Center as well as other empirical research studies (Holton; Chyi, 2012; Goyanes, 2014). Consumers' paying behavior was measured asking respondents: "Are you currently paying for your favorite online newspaper?" $0=$ No; 1 = Yes. Finally, controls (demographics: age, gender, and income) were collected by standard survey measurements.

The analysis revealed age as a significant and negative predictor of news overload

The model constructed in this research is based on a hierarchical multiple regression with the aim of predicting readers' perceptions of news overload. Based on the theoretical framework developed, the predictor variables were entered in the equation in three different blocks: demographics (gender, age and, income), news interest, and finally consumers' paying behavior. A multicollinearity test confirmed that no independent variables were highly correlated with each other.

\section{Results}

Regression analysis was conducted to answer the three research questions posed in the theoretical framework. Only the RQ1 can be answered with a frequency analysis. The descriptive statistics and correlations of the quantitative variables are presented in Table 1 . From the total sample of 1,439 Spanish adults, only 6.7 percent $(N=97)$ and 19.0 percent $^{4}(N=273)$ of respondents indicated they completely or mostly disagreed with the statement "I often feel overload

Table 1. Descriptive statistics and correlations of quantitative variables. ${ }^{*} p<0.05 ; * * p<0.01$

\begin{tabular}{|l|c|c|c|c|c|c|}
\hline & $\boldsymbol{M}$ & $\boldsymbol{S D}$ & $\mathbf{1}$ & $\mathbf{2}$ & $\mathbf{3}$ & $\mathbf{4}$ \\
\hline Age & 50.93 & 17.65 & 1.00 & $0.09^{* *}$ & $-0.14^{* *}$ & $-0.05^{*}$ \\
\hline Income & 4.84 & 2.31 & $0.09^{* *}$ & 1.00 & $0.09^{* *}$ & -0.01 \\
\hline News interest & 3.41 & 0.85 & $-0.14^{* *}$ & $0.09^{* *}$ & 1.00 & $-0.06^{*}$ \\
\hline Overload & 2.95 & 0.86 & $-0.05^{*}$ & -0.01 & $-0.06^{*}$ & 1.00 \\
\hline
\end{tabular}

with the amount of news available these days". Therefore, most of the respondents' perceptions of news overload were very high. Most of the respondents mostly agree (44.1 percent; $N=635)$ while 27.3 percent $(N=393)$ completely agree. The answers to the rest of the research questions (RQ2 and RQ3) are presented in table 2.

It might be the case that the relationship between news satisfaction and news overload is moderated by the fact that the reader is actually paying for content or not

Hierarchical regression analysis was conducted to examine the relationship between demographics, news interest, and consumers' paying behavior on news overload. All three models were statistically significant as well as the $R^{2}$ change $(p<0.05)$. Demographics (age, gender, and income) were entered on the first step of the regression analysis. Only age had a significant and negative association with news overload $(B=-0.008 ; p<0.05)$. Therefore, younger people felt more overloaded with the news available today when compared with older people. Both gender and income did not statistically influence the perception of news overload. This first model only accounted for 2 percent of the variance in news overload $\left(R^{2}=0.02\right)$.

News interest was entered at the second step of the hierarchical regression analysis. In addition to age $(B=-0.007$; $p<0.05)$, news interest was also a significant and negative predictor of news overload $(\theta=-0.168 ; p<0.05)$. Therefo$r e$, the higher the users' news interests were the lower the perception of news overload was. This second model accounted for the 7 percent of the variance of news overload $\left(R^{2}=0.07\right)$. Finally, consumers' paying behavior was entered on the fourth step of the hierarchical regression analysis. In addition to age $(B=-0.009 ; p<0.05)$ and news interest $(B=$ $-0.187 ; p<0.05$ ) consumers' paying behavior was a significant and negative predictor of news overload $(B=-0.545 ; p$ $<0.05)$. Therefore, people who were paying for access to a favorite online newspaper suffered less news overload with respect to those readers who consumed free information. This fourth model accounted for 15 percent of the variance of news overload $\left(R^{2}=0.15\right)$.

Table 2. Hierarchical regression analysis of predictors of news overload. ${ }^{*} p<0.05 ;{ }^{* *} p<0.01$

\begin{tabular}{|l|c|c|c|}
\hline & Block 1 & Block 2 & Block 4 \\
\hline Gender & 0.063 & 0.067 & 0.018 \\
\hline Age & $-0.008^{* *}$ & $-0.007^{* *}$ & $-0.009^{* *}$ \\
\hline Income & 0.001 & 0.003 & 0.002 \\
\hline News interest & & $-0.168^{*}$ & $-0.187^{*}$ \\
\hline WTP & & & $-0.545^{* *}$ \\
\hline F statistic & $8.67^{* *}$ & $7.85^{* *}$ & $3.41^{* *}$ \\
\hline$R^{2}$ & 0.02 & 0.07 & 0.15 \\
\hline Adjusted $R^{2}$ & 0.00 & 0.03 & 0.11 \\
\hline
\end{tabular}




\section{Discussion and conclusions}

The research presented in this article explored factors that negatively or positively correlated with the perception of news overload and the extent to which Spaniards feel overloaded with the amount of news available. Specifically, the study explored the following factors: demographics (age, gender, and income), news interest, and consumer paying behavior. To that end, the research employed a quantitative, explorative approach with data collected from an online survey of 1,439 Spanish adults, 18 years and older, in January 2013. Using a hierarchical multiple regression analysis, the results of the study indicate a perception of news overload among Spaniards and a significant and negative relationship between age, news interest, and consumers' paying behavior.

\section{Younger generations have considerable exposure to various information outlets, and can be expected to be more suscep- tible to news overload}

The results of this study point to several possible theoretical and managerial implications. First, the analysis revealed age as a significant and negative predictor of news overload in all three models. To a certain extent these results replicated Williamson and Eaker's (2012), Honton and Chyi's (2012), and Ji, $\mathrm{Ha}$ and Sypher's (2014) findings that age negatively correlates with the perception of news overload; young adults are generally more likely to suffer news overload. However, this study is unlike the previous studies, which were conducted in the US, because it did not find gender (being female) or income (positive) as a significant predictor of news overload.

What are some possible explanations for our findings? Currently there are multiple sources from which people can obtain their information and communication(iPad, iPhone, PC, Netbook, etc.).

Younger generations, in both Spain and the US, have had considerable exposure to various information outlets (Pew Research Center, 2013), and can be expected to be more susceptible to news overload (Ji; Ha; Sypher, 2014). On the other hand, the data indicated a non-significant relationship when correlating gender and income to news overload (which is surprising when compared to previous studies in the US). This finding and comparison with previous studies highlights the difficulty of generalizing research from one country's population to another when they have differing cultural, economic, and social backgrounds. Future research should explore the cultural, gender, and socio-economic differences between countries as they relate to the feeling of news overload.

This study also found news interest was a negative predictor of news overload, suggesting that people who are interested in news are actually less, not more, overloaded with the information available. The results are supported by previous empirical research (Holton; Chyi, 2012). A possible explanation for this result may be the readers' consumption habits; perhaps people who are interested in news are capable of filtering exactly what they are looking for or want to consume (Savolainen, 2007) through different channels and time schedules and are, therefore, able to decrease the perception of news overload. In comparison, perhaps "sporadic" readers who do not particularly enjoy reading the news feel overloaded with the amount of information and consequently lost in decoding and processing complicated news stories (Thompson, 2009). To some extent, what this research indicates is that filtering (Shirky, 2008) and organizing the news through different software programs and according to ones' personal capacity would lead to a decrease in the level of news overload. The personalization of information delivery by news organizations would be, therefore, a suitable strategy in assisting consumers in avoiding the perception of news overload.

This study also provides an empirical foundation for future research into news overload by analyzing a statistically significant and negative predictor of news overload, consumer paying behavior. Readers who are currently paying for their favorite online newspaper are less likely to feel overloaded than those who do not pay and instead consume only free news. This finding suggests that online newspapers with paid content strategies serve as filters for the readers' consumption of digital information. The development of computer software programs that personalize (and also interact and help to customize) the news to fit the needs and wants of the readers may help explain this finding.

This result proposes a new research avenue for future research since, it is more than probable that people who feel satisfied with the information provided by news organizations (no matter whether the organizations develop free or paid content strategies) also suffer more news overload than those who are not. However, in online newspapers with paid content strategies, despite the fact that it is more than probable also that the satisfaction with the information provided is high, the news overload experimented (by the paid readers) is low. Maybe, users who have high desire and not paying for news subscription will feel greater news overload, as compared to those with high desire but paid for news subscription. Therefore, it might be the case that the relationship between news satisfaction and news overload is moderated by the fact that the reader is actually paying for content or not.

\section{Filtering and organizing the news through software programs and accor- ding to ones' personal capacity would lead to a decrease in the level of news overload}

\section{Future studies and limitations}

This study has weaknesses that should be addressed in future research. Because there is no generally embraced operationalization of news overload and news interest, the present study used single-item measures for these two variables, which may limit the construct validity of the study. 
One consequence of the use of single items might be the low $\mathrm{R}^{2}$ showed in the hierarchical regression analysis, since only costumers' paying behavior considerable increment the explained variance in news overload. However, in both cases (news overload and news interest) the measurement technique was adapted from previous empirical research (Holton; Chyi, 2012; Ji; Ha; Sypher, 2013).

Future studies focused on the analysis of news overload should expand the selection of predictor variables used in the regression models, and more specifically, incorporate personal characteristics or personality factors that might explain a large percentage of variance in news overload. Also, researchers should empirically measure possible interaction effects, since this would extend our knowledge of the phenomena and open new avenues of research (for example, the interaction between consumers' satisfaction and paying behavior). Finally, the development of a more reliable scale to measure news overload that incorporates items such as the feeling of being overwhelmed, perceived manageability of information, and so forth, would be highly beneficial.

\section{Notes}

1. In Spain, various online media are used for news consumption: 56 percent of Spanish adults access news via computer, 35 percent via smartphone and 13 percent via tablets (Reuters, 2013; $n=979$ ). Multiplatform use might not be as prevalent in Spain as in the US, but can reasonably be expected to grow.

2. Timing was not a factor to consider.

3. That is, the number of people who completed the survey divided by the number of people who responded to the survey invitation.

4. A total of 25.7 percent of respondents.

\section{References}

Atkinson, Rowland; Flint, John (2001). "Accessing hidden and hard-to-reach populations: Snowball research strategies". Social research update, v. 33, n. 1, pp. 1-4.

http://sru.soc.surrey.ac.uk/SRU33.pdf

Bawden, David (2001). "Information overload". Library \& information briefings, n. 92, pp. 1-15.

Bawden, David; Holtham, Clive; Courtney, Nigel (1999). "Perspectives on information overload". Aslib proceedings, v. 58, n. 8 , pp. $249-255$.

http://dx.doi.org/10.1108/EUM0000000006984

Bawden, David; Robinson, Lyn (2009). "The dark side of information: overload, anxiety and other paradoxes and pathologies". Journal of information science, v. 35, n. 2, pp. 180-191.

http://www.bollettinoadapt.it/old/files / document/21976david_b-2008.pdf

http://dx.doi.org/10.1177/0165551508095781

Bregman, Peter (2012). "Coping with email overload". Harvard business review, 26 April.

http://blogs.hbr.org/2012/04/coping-with-email-overload
Chyi, Hsiang-Iris; Chadha, Monica (2012). "News on new devices: Is multi-platform news consumption a reality?". Journalism practice, v. 6, n. 4, pp. 431-449.

http://www.tandfonline.com/doi/pdf/10.1080/17512786.2 011.629125

http://dx.doi.org/10.1080/17512786.2011.629125

Diddi, Arvind; LaRose, Robert (2006). "Getting hooked on news: Uses and gratifications and the formation of news habits among college students in an Internet environment". Journal of broadcasting \& electronic media, v. 50, n. 2, pp. 193-210.

http://dx.doi.org/10.1207/s15506878jobem5002_2

Goyanes, Manuel (2014). "An empirical study of factors that influence the willingness to pay for online news". Journalism practice, pp. 1-16.

http://www.tandfonline.com/doi/full/10.1080/17512786.2 014.882056\#.VFCz64twsug

http://dx.doi.org/10.1080/17512786.2014.882056

Goyanes, Manuel; Dürrenberg, Catherina (2014). "A taxonomy of newspapers based on multi-platform and paid content strategies: Evidences from Spain". International journal on media management, v. 16, n. 1, pp. 27-45. http://dx.doi.org/10.1080/14241277.2014.900498

Hallowell, Edward (2005). "Overloaded circuits". Harvard business review, January.

http://www.integrity-plus.com/eStore/WP/overload\%20 circuitsR0501Ef2.pdf

Hermida, Alfred (2010). "Twittering the news: The emergence of ambient journalism". Journalism practice, v. 4, n. 3, pp. 297-308.

http://dx.doi.org/10.1080/17512781003640703

Holton, Avery; Chyi, Hsiang-Iris (2012). "News and the overloaded consumer: Factors influencing information overload among news consumers". Cyberpsychology, behavior, and social networking, v. 15, n. 11, pp. 619-624.

http://dx.doi.org/10.1089/cyber.2011.0610

Ji, Qihao; Ha, Louisa; Sypher, Ulla (2014). "The role of news media use and demographic characteristics in the possibility of information overload prediction". International journal of communication, v. 8, pp. 699-714.

http://ijoc.org/index.php/ijoc/article/viewFile/2419/1093

Kirsh, David (2000). "A few thoughts on cognitive overload". Intellectica, v. 1, n. 20, pp. 19-51.

http://adrenaline.ucsd.edu/kirsh/Articles/Overload/ Cognitive_Overload.pdf

Mitchell, Bill (2013). "How two small family-owned newspapers in Vermont had success with a paywall".

http://www.poynter.org/latest-news/top-stories/222073/ how-two-small-family-owned-newspapers-in-vermont-hadsuccess-with-a-paywall

Nordenson, Bree (2008). “Overload!". Columbia journalism review, 30 Nov.

http://www.cjr.org/feature/overload_1.php?page=all

Pew Research Center. (2010). State of the news media 2010. http://stateofthemedia.org/2010 
Pew Research Center (2014). State of the news media 2014. http://www.journalism.org/packages/state-of-the-newsmedia-2014

Picard, Robert (2003). "Cash cows or entrecote: Publishing companies and disruptive technologies". Trends in communication, v. 11, n. 2, pp. 127-136.

http://wiiau4.free.fr/pdf/CashCows.pdf

http://dx.doi.org/10.1207/S15427439TC1102_04

Reuters (2013). Reuters digital news report.

http://www.digitalnewsreport.org

Savolainen, Reijo (2007). "Filtering and withdrawing: strategies for coping with information overload in everyday contexts". Journal of information science, v. 33, n. 5, pp. 611-621. http://dx.doi.org/10.1177/0165551506077418

Serra, Marcello (2012). "Wikileaks: el poder entre bastidores". Estudios sobre el mensaje periodístico, v. 18, n. 1, pp. 211-220. http://dx.doi.org/10.5209/rev_ESMP.2012.v18.n1.39366

Shirky, Clay (2008). "It's not information overload. It's filter failure". Web 2.0 Expo NY.

http://blip.tv/web2expo/web-2-0-expo-ny-clay-shirky-shirkycom-it-s-not-information-overload-it-s-filter-failure-1283699
Stone, Linda (2008). "Continuous partial attention. Not the same as multi-tasking".

http://lindastone.net/qa/continuous-partial-attention

Swartz, Jon (2011). "Social media users grapple with information overload". USA today, 2 Febr.

http://usatoday30.usatoday.com/tech/news/2011-02-01tech-overload_N.htm

Thompson, Matt (2009). "An antidote for web overload". Nieman reports.

http://niemanreports.org/articles/an-antidote-for-weboverload

Thornton, Glenda (2007). Information tomorrow: Reflections on technology and the future of public and academic libraries. Medford, NJ: Information Today. ISBN: 978157387 3031

http://dx.doi.org/10.1080/01462670802368232

Vogt, Paul; Johnson, Burke (2011). Dictionary of statistics \& methodology: A nontechnical guide for the social sciences. Thousand Oaks: Sage. ISBN: 9781412971096

Williamson, Jeanine; Eaker, Christopher (2012). "The information overload scale". Asist 2012, Baltimore, MD.

\section{El profesional de la información} The information professional

\section{EPI deja la edición en papel}

Adaptándose a los nuevos tiempos, a partir del próximo mes de enero de 2015 esta revista El profesional de la información va a publicarse sólo online.

Al mismo tiempo, debido al cese de actividad en abril de 2015 de la empresa MetaPress, del grupo Ebsco, la revista se instalará en el Repositorio Español de Ciencia y Tecnología (Recyt) de la Fundación Española para la Ciencia y la Tecnología (Fecyt):

http://recyt.fecyt.es/index.php/EPI

Desde ahí los suscriptores podrán acceder a los contenidos desde el año 2000 hasta la actualidad.

La web http://elprofesionaldelainformacion.com continuará funcionando como ahora, con toda la información sobre la revista, y los contenidos 1992-2010. 